\begin{tabular}{|c|}
\hline Journal of Political Science \\
(A Peer-Reviewed, Open Access International Journal) \\
ISSN 2362-1273 (Print); ISSN 2773-8132 (Online) \\
Volume 21, February 2021, pp. 86-99 \\
https//: www.ejournal of pncampus.edu.np/journals/ips/ \\
\hline
\end{tabular}

\title{
Diaspora Diplomacy: Emerging Priority of Nepal's Foreign Policy
}

\author{
Pratima Sharma \\ Ministry of Foreign Affairs \\ Government of Nepal
}

Corresponding Author: Pratima Sharma, Email: smileypratima@gmail.com

DOI: https://doi.org/10.3126/jps.v21i0.35267

Received 2 December, 2020, Reviewed 15 December 2020, Published 1 February 2021

\begin{abstract}
Many people from Nepal are currently living in foreign countries. Their living has become a prominent issue in foreign policy and international relations as it has a broader impact on the bilateral connection between Nepal and the host countries as well as in the development back home. Appropriately mobilizing diverse potential inheritance in the Nepali diaspora can be a real boon for Nepal in achieving the national goals. The government is working on that by devising various policies, but the results are not satisfactory. Rigorous homework is yet to be done at the policy-making level to maximize achievements through the effective conduction of diaspora diplomacy. Hence, shedding light on the broader perspective of the Nepali diaspora, this paper attempts to focus on their role in the social, economic and cultural development of Nepal. The new institutional and policy arrangements that policymakers should adopt in upcoming days to address diaspora needs and to maintain a balanced relation between the government and Nepali community residing outside the border are also discussed. The article is descriptive and analytical in format, and the data are collected from secondary sources.
\end{abstract}

Keywords: Brain-gain center, diasporas, economic diplomacy, globalization, non-resident Nepali

\section{Introduction}

The modern-day globalized world has made the movement of people from one county to another swift and easy. People originating from one country, including their descendants, can live or work in another country and enjoy a special bond with their home country, whom we call 'diaspora'.

Diaspora, an English term, entered into usage in 1876. It is derived from the Greek word 'diaspeirō,' which means scattering. Historically, diaspora indicates the forceful dispersion 


\section{Diaspora Diplomacy: Emerging Priority of Nepal’s Foreign Policy}

of Jewish people from Israel to live in other parts of the world. It now implies the people who have moved to another country recently or earlier intending to live, either for shorter and temporary or for a extended and permanent time but have a special connection towards the country of their origin (Agunias \& Newland, 2012).

The term "diplomacy” is derived from the Greek word 'diploma' that indicates an official document by which a privilege is conferred. Edmund Burke first introduced the term 'diplomacy' in 1796 (Acharya, 2015). Diplomacy is a means devised for achieving the aims and objectives of a nation expressed in terms of foreign policy. So, if the foreign policy is the end, diplomacy is the means. In the 21st century, new kinds of challenges resulting from interdependence among states and globalization have had a determining impact on diplomacy. Diplomacy has become multifaceted, multi-directional, volatile, and intensive due to the increased complexity in terms of actors, dialogues subjects, modes of communication, and the plurality of objective (Rana, 2011). These global system changes require a paradigm shift in priorities from problem-solving diplomacy by building institutionalized assistance to the diplomacy of managing relationships between people (Sharp, 2019).

There has been a notable rise in non-state actors (international, private, and transnational), creating a more significant impact in explaining the theory of International Relations and its usage in the modern twenty-first century. So, non-state actors must be given great importance while conducting foreign policy research (Stengel \& Baumann, 2017). Hence, international relations is no more a state affair only; non-state actors like the diaspora community also has an essential role to execute nowadays.

Diaspora diplomacy indicates the shared actions of a wide range of immigrants who influence diverse aspects in the country of their ancestors and the culture, politics, and economy of the country of their settlement. And no doubt, both the countries are mutually benefited (Gonzales, 2012).

All countries are not clear on the concept of their "diaspora diplomacy." But diasporas are the vital means to expand foreign relations. Compared to past years, the nation's responsibility to protect its nationals in foreign lands has become more prominent these days because they are more vulnerable to problems like terrorism and natural calamities in the host countries. So, the importance of diaspora diplomacy is sure to increase as people migrating to another country are ever-rising (Rana, 2011).

Hence, diaspora diplomacy has garnered a significant attention in today's interrelated world. The increasing movement of people has forced the stakeholders to get engrossed in formulating and executing required policies at home as well as in government-togovernment interactions to formulate liberal policies in the host countries. A considerable percentage of Nepali human resources is currently outside the national boundary. They are continuously playing an overarching role in transforming Nepali society and enhancing national identity on the international platform. Thus, they deserve to be addressed by the policymakers more responsibly so that their rights are protected, and they are further encouraged to perform their responsibility in national development. In the context of the increasing influence of globalization in Nepal, some questions like; What are the current issues and problems Nepali diasporas are facing? Are the policies adopted by the government to address diaspora needs enough in the present context? And what could be the new road map for effectively mobilizing the skills inheritance in diasporas? are assured 


\section{Diaspora Diplomacy: Emerging Priority of Nepal’s Foreign Policy}

to arise. Thus, this article tries to find answers to these questions. This article also discuses about the history as well as current status of the Nepali diaspora highlighting their socioeconomic and cultural impacts.

\section{Objective and Methodology}

The main objective of this article is to explore the mounting priority of Nepal in diaspora diplomacy. The article also aims to highlight the Nepali diaspora's role in the country's economic development through remittance and investment. This article is descriptive and analytical in format. The required data is obtained through various secondary sources like books, journals, national-international reports, newspapers, government portals, and previous research works. The nature of the data is qualitative.

\section{Literature Review}

Diaspora diplomacy is well known as the use of Foreign Service, or other branches of government, to endorse the systematic relationship, for mutual benefit, between the country of origin, diaspora groups in the nation of residence, and the various interest associations in both the country of origin and country of residence (Birka \& Klaviñš, 2020). As the trend of migration of people from one nation to another is ever increasing, the government of the country of origin has established different legal and institutional mechanisms to get connected with their diasporas in different countries.

The institutionalization of "diaspora diplomacy" showcases that a country's diaspora community has become considerably more important as a subject of interest for foreign policy and associated government activities (Emre OK, 2018). Several researchers have conducted research works in this field in different countries.

Adopting a well-defined foreign policy of Nepal recently in October 2020, the government of Nepal has appreciated the contribution of Nepali diaspora to the country's socioeconomic transformation through economic diplomacy and has set the goal to protect the Nepali community involved in any profession, business, and employment in foreign countries. The document has also indicated the special priority of promoting Nepal's soft power through Nepal's extraordinary natural beauties, unique and affluent civilization, cultures, lifestyle, thoughts, diversity, art, language, literature, and sports and has also acknowledged the power of the Nepali diaspora in enabling this objective. Thus, this paper tries to analyze the roles of Nepali diasporas in today's governance system in the attainment of national interest as set by the government of Nepal in the present global context.

\section{Theoretical Perspective}

The concept is determined by several theories. The diaspora analysis is based on a broader context of academic concern. The concept is closely concerned with the liberal school of thought. The liberal approach emphasizes the great potential for human progress in the 


\section{Diaspora Diplomacy: Emerging Priority of Nepal’s Foreign Policy}

modern civil society and the capitalist economy, both of which can flourish in states which guarantee individual liberty. Freedom and democracy are the core values of relations of this school of thought. The liberalists are more optimistic about the prospects for peace and see the rules of international relations as slowly, incrementally evolving through time and potentially becoming more and more peaceful (Goldstein \& Pevehouse, 2008, p. 84). This evolution results primarily from the gradual build-up of international organization and mutual cooperation and secondarily from changes in norms and public opinion. The liberals claim that the world has seemingly progressed in terms of reducing the level of violent conflict. Open economies, trade, and interdependence have also contributed to this decline of violence (Walker \& Rousseau, 2018, p. 29). The movement of Nepali people in the past was limited but became more common after the restoration of multiparty democracy in 1990. The policy of liberal democracy adopted by the government paved the way for easy movement of people outside the country.

\section{The Nepali diaspora}

Nepali diaspora indicates Nepali people living and working outside Nepal. It is often synonymous with Non-resident Nepalis. Non-resident Nepali Act, 2008 has, to some extent, tried to introduce Nepali diaspora in different terms which say:

(a) "Non-resident Nepali" means a foreign citizen of Nepali origin, and this term also includes a Nepali citizen residing abroad (Article 2(a)).

(b) "Foreign citizen of Nepali origin" means a person who him/herself or whose father, grandfather or grandmother was a citizen of Nepal at any time and has subsequently acquired the citizenship of any other foreign country other than a member country of the South Asian Association of Regional Co-operation (SAARC) (Article 2(b)).

(c) "Nepali citizen residing abroad" means a Nepali citizen who has been residing in any foreign country for at least two years by doing any profession, occupation, business and employment except a Nepali citizen living in a member country of SAARC or Serving in a diplomatic mission or consulate situated in a foreign country under the assignment of the government of Nepal and doing the study in an academic institution located in a foreign country (Article 2(c).

Nepali Diaspora includes not only non-resident Nepalis, foreign citizens of the Nepali origin, and Nepali citizens residing in countries outside the SAARC region but all Nepalis and the people of the Nepali origin and their communities all over the world.

\section{History of Nepali Diaspora}

The movement of the Nepali people to other countries started centuries ago. But it was initially limited within the countries of the Asian region. Later on, factors like globalization contribute to their expansion in many countries around the globe. 


\section{Diaspora Diplomacy: Emerging Priority of Nepal’s Foreign Policy}

After Nepal was declared a unified country in 1768 by King Prithvi Narayan Shah, Nepal started to be the main trade route from India to Tibet via Kathmandu valley. Some Newar (an ethnic community in Nepal) artisans invited to move to the valley in the seventeenth century started being active in trade-related activities and traveled to Tibet and settled as artisans and traders; in Shigatse, Gyantse, and Lhasa. Thus, if one were to speak of a Nepali diaspora before 1850 , it could only have referred to the Newars, Kathmandu valley's inhabitants. On the other hand, some Nepalis saw the Newars as a trading diaspora, though many are, in fact, artisans, peasants, and laborers rather than shopkeepers and merchants (Gellner, 2013).

There was evidence that a growing number of Nepali Brahmans came to live at Kashi, Banaras in India in the eighteenth century. The Nepali settlement in Banaras was initially linked to Kashi's role as the center of learning. Hill Brahmans came there to learn Sanskrit, and many settled there (Gaenszle, 2002).

The British entry into the South Asia also has a significant role in expanding the Nepali diaspora outside India and China. The Anglo-Nepali War (1814-16), fought between the Gorkha Kingdom (now the Federal Democratic Republic of Nepal) and the East India Company, left a lasting impression on the British. They were highly impressed with Nepali brevity and courage. As an appreciation, they gave Nepali soldiers the name 'Gurkhas.' Onward this, the Nepali men's recruitment as soldiers for Britain got started (Gellner, 2013).

After India got independence, a tripartite agreement was signed among England, Nepal and India in 1947 to settle the Gurkhas' future in military service (Gellner \& Hausner 2018). The British took four regiments of the Gorkha Rifles while the other six remained with the Indian Army. In the mid-fifties of the ninetieth century, there was large-scale recruitment of the Nepalis in the British Army to quell Malaya's communist insurrection. Thousands of Nepali soldiers fought the World War I and II in British favor. Likewise, during the IndiaChina war in 1962 and the Indo-Pakistan wars in 1965 and 1971, many Nepalis were recruited in the Indian Army (Caplan, 1995).

Even today, thousands of Nepalis are serving in the United Kingdom and India as British and Indian soldiers. Thus, one of the main ways Nepali moved abroad, often deciding to stay overseas was through their service as Gurkha soldiers. The soldiers and their families constitute a significant Nepali diaspora community in countries like the United Kingdom, India, Singapore, Brunei, and Burma. Thus, Gurkha's history of Nepal, which helped to glorify Nepal's identity as a 'Land of Gurkhas' in the world, played an excellent role in expanding the Nepali community in various countries in and outside Asia.

\section{Nepali Diaspora Today}

As far as the modern Nepali Diaspora is concerned, three categories of migration can be highlighted: first, overland, mainly seeking work, and mostly towards the east; second, again overland, but more focused on pursuing work in Indian cities; and finally, third, traveling by plane to work in the Gulf (or 'Arab' as Nepalis refer to it), in Southeast Asia, and beyond, or for education and work in the developed world (Gellner, 2013).

Among the countries with the highest level of migration, Nepal was at the top 9 during 2000-2010 and now at the top 7 during 2010-2020 as per the International migration report, 


\section{Diaspora Diplomacy: Emerging Priority of Nepal’s Foreign Policy}

2019. According to the national census, 2011, Nepal's total population in foreign countries (except India) was 1,921,494, while the data reached 4,365,415 till the mid of 2018 (Economic Survey, 2018/19). The data also shows that, institutionally, Nepal has opened 110 countries for foreign employment. However, more than 167 countries have been opened for foreign employment on an individual basis. The 2011 census on population and housing shows that almost $50 \%$ of Nepal's households had a member who was either working overseas or had returned. This data is astounding. The data also shows that about two-thirds of Nepali migrants are in India. But the information is still incomplete because an open border with India has resulted in a comfortable, undocumented, and temporary movement of people across the border.

The exact number of people of Nepali origin and their descendants residing in various other developed countries with permanent resident cards or citizenship cards is yet not documented. But it is supposed to be in millions in number. In the United States alone, 140,000 Nepali lived until 2015 (Pew Research Center, 2017).

Nepali students and their families also constitute a great number among Nepali Diaspora in various countries. The exact number of Nepali students who sought permission to go abroad to study until August 2019 was 323,972 (Foreign Education Department, 2019). As per the data from the last eight years, an average of 200 Nepali students left the country for foreign studies in as many as 69 countries. Countries like India, China, Australia, Japan, South Korea, New Zealand, United Kingdom, United States, France, and Germany hold the maximum number (Nepali Sansar, 2019).

\section{Socio-economic and cultural significance of Nepali Diaspora}

Nepali Diasporas offer a myriad of benefits and opportunities to Nepal. Among many, socioeconomic and cultural benefits are highlighted here:

\section{Role in social transformation}

Nepal is a developing country. Compared to other developed countries, Nepal is backward in terms of the opportunity to fulfill many fundamental human needs. Most people are so innocent and follow old social taboos like 'Chhaupadi' (Chhaupadi is a tradition of "untouchability" in the far-western Nepal where women and girl are required to live away from the community, typically in a livestock shed, and are forbidden from touching other people and objects, during menstruation), 'Dowry system' (Dowry system is a practice of giving money or property or some kinds of special gifts at the marriage of a daughter by the father to bridegroom or bridegroom's family), etc. But as people got the opportunities to see the changes and advancement in other countries, the social transformation happened. People understood the importance of education. The literacy rate of Nepal was just 33\% in 1990, while it is $68 \%$, according to the census, 2011. People are now getting the opportunity to know technological development on the global front. The use of social applications like Facebook, Viber, Messenger, etc is increasing the connection between families and friends. People are now smarter, techno-friendly, and educated due to their exposure to the outside world.

The effort of individual Nepali Diaspora like Shesh Ghale, the first billionaire in the global Nepali Diaspora (the Australian Financial Review 2019 Rich List, 2019) is commendable. 


\section{Diaspora Diplomacy: Emerging Priority of Nepal's Foreign Policy}

He is doing numerous humanitarian works in Nepal at various times of crisis. Following the 2015 mega-earthquake, when he was the president of the Non-resident Nepali Association (NRNA), Ghale led well-coordinated relief and reconstruction activities in affected areas. To help underprivileged and vulnerable Nepal's communities through education and health, Ghale and his wife co-founded the MIT Group Foundation in 2015 and continued doing social works in Nepal. Recently, this couple donated NRS 3 million (estimated 28,000 USD) to Nepal's government for combating the COVID-19 pandemic (MIT Group Foundation, 2020). Likewise, the institutional efforts of NRNA are praiseworthy. It is doing various social works in Nepal. Currently, it is trying hard to create awareness among Nepali people, distribute safety equipment, and help the Nepali migrants residing in multiple countries to minimize risks of coronavirus among the Nepali population. NRNA and the International Labor Organization (ILO) signed a project in June 2020 for the repatriation and return of the Nepali Migrant workers in response to COVID-19. With monetary aid from the Government of Switzerland, as a part of the ILO's Migrant Rights and Decent Work (MIRIDEW) Project, this initiative aims to work together with Nepali diplomatic missions in Malaysia, Saudi Arabia, Qatar, and UAE to provide active services to Nepali migrant workers. It also provide legal/para-legal aid and short-term shelter support for the most vulnerable Nepali migrant workers and support Nepal Government in offering safe and secure transit services to returning Nepali migrant workers back in Nepal (Non-resident Nepali Association, 2020).

An international think-tank and a knowledge-platform dedicated to the sustainable development of Nepal and the Nepali-people, including diaspora Nepali 'Nepal Policy Institute' (NPI), has been recently established in Hague, the Netherlands with the efforts of Non-resident Nepali. This institution aims to collaborate with the Government of Nepal and other research wings to make sound development policies in Nepal.

\section{The backbone of national economy}

The migration of people has consistently been an essential source of remittance. Foreign jobs have been a viable option for many countries to fight against poverty and unemployment. It has helped improve people's living standards and bring socio-economic transformation (Livitt, 2001). Nepal is not an exception. Migration has played a significant role in bringing a multitude of positive effects on Nepal's economy, improving the living standard of Nepali people, and solving the existing unemployment problem, to a greater extent.

Around $70 \%$ of Nepali are engaged in agriculture. But agriculture alone has been unable to provide enough employment opportunities for the people. Each year around 500,000 Nepali youths enter the job market, but the government has not offered job opportunities to all of them. Nepal Labour Force Survey (NLFS, 2017/18) shows that Nepal's existing unemployment rate is $11.4 \%$. Thus, foreign employment has been a lucrative job option for them. The contribution of remittance to GDP was about $0.70 \%$ during 1975-1990, which increased to 21.41\% during 2009-2015. According to World Bank Report 2020, Nepal received $\$ 8.1$ billion as a remittance in 2019, which constituted $27.3 \%$ of the total national GDP. Hence, the Nepali Diaspora are playing an essential role in rolling the economy of the country. The given figure shows the trend of remittance inflow in Nepal: 


\section{Diaspora Diplomacy: Emerging Priority of Nepal’s Foreign Policy}

Figure 1

Trend in obtaining labor permits (Left) and incoming remittance (Right)

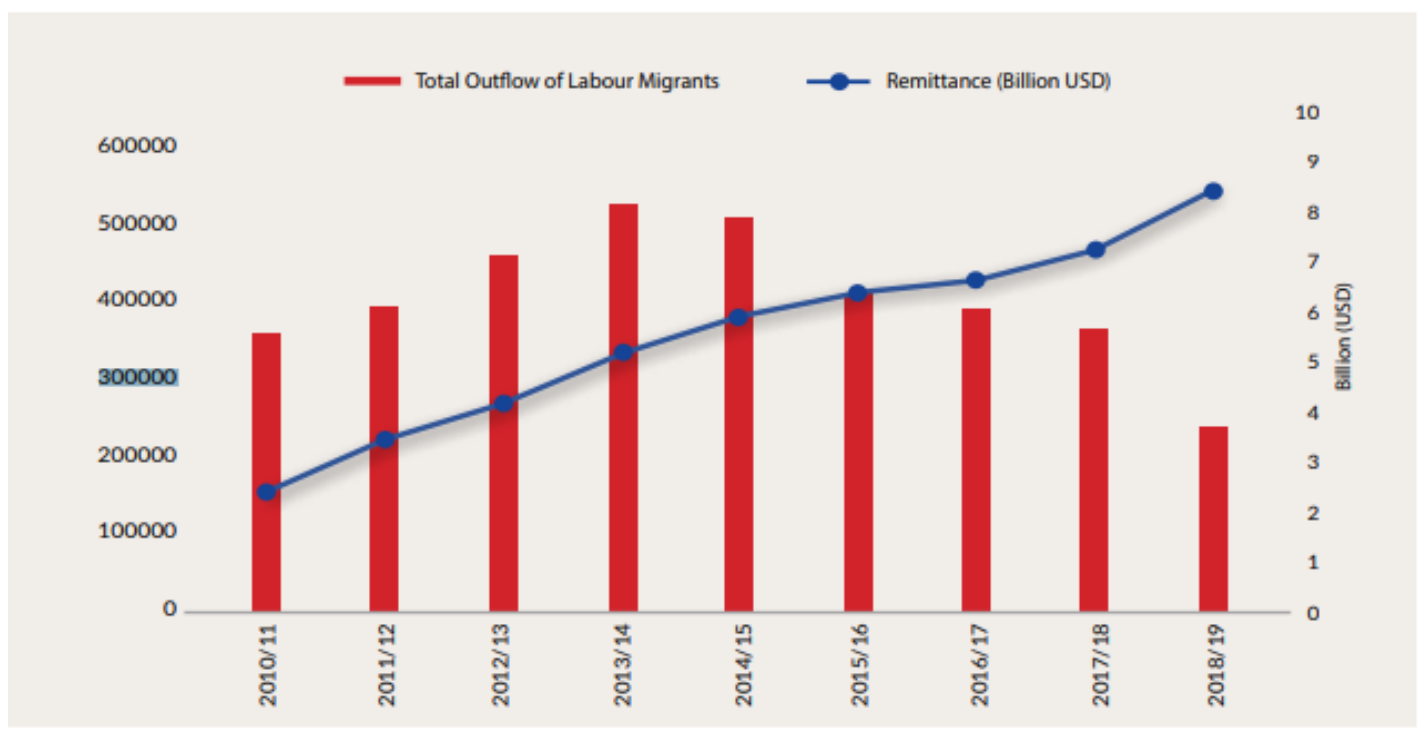

Source: Foreign Employment Information Management System and Nepal Rastra Bank, 2019.

Non-Resident Nepalis are also investing their capital and resources in various sectors like hydropower, tourism, bank, financial institutions, agriculture, education, real estate, etc. Their investment has contributed significantly to the employment generation and economic development of Nepal. As the most prominent association of Nepali Diaspora, NRNA is extending thousands of philanthropic and social services in Nepal, like constructing nursing homes, death funeral houses, hospitals, roadways, drinking water supplies, etc. (NRNInvestment in Nepal, 2015). Hence, Nepali Diasporas are one of the prominent contributors to the economy and development of Nepal.

\section{Promotion of Nepal and Nepali culture}

Migration has not only helped in socio-economic transformation but also in transferring social norms and values, skills and ideas, culture, and civilization from one country to another (Livitt, 2001). Nepali residing in various countries are the cultural ambassadors as they have helped foster Nepali culture, literature, art and music, traditions, food, festivals, and identity. They have helped enhance the national image as the land of the highest peak and the birthplace of Buddha. Increased interaction of Nepali Diaspora with people of host countries has further helped uplift people-to-people relations. We often see many foreigners celebrating Nepali festivals like Dashain, Tihar, Holi, etc., with Nepali families in foreign lands. This has helped in the assimilation of Nepali culture and tradition globally, which has contributed to public diplomacy and cultural diplomacy. 


\section{Diaspora Diplomacy: Emerging Priority of Nepal’s Foreign Policy}

Nepali diplomatic missions also organize programs like cultural shows, carnivals, feasts and fairs to promote Nepal by collaborating with Nepali Diaspora in various countries time and again (The Ministry of Foreign Affairs, 2019).

\section{Government and Nepali diaspora}

The government of Nepal has embraced its responsibility to protect its national both at home and abroad. It, too, has adopted different policies to encourage them to engage in various social and economic activities in Nepal. The Ministry of Foreign Affairs, the Ministry of Labour, Employment and Social Security, other related Ministries and Departments, and the diplomatic missions stationed at capitals of various host countries are now extensively engaged in a wide array of work related to Nepali Diaspora. Centering the priority to address the needs of migrants' labor, the number of high-level visits from Nepal to various labor destination countries is also increasing. Labour Agreements and Memorandum of Understandings (MoUs) have also been signed with many of the countries.

The present constitution of Nepal has given special attention to Non-Resident Nepali needs, especially regarding their right to hold Non-Resident Nepali Citizenship cards. It reads as:

The non-residential citizenship of Nepal may be so granted to a person who has acquired the citizenship of a foreign country, has resided in a country other than a member state of the South Asian Association for Regional Cooperation, and who or whose father or mother, grandfather or grandmother was previously a citizen of Nepal by descent or birth but subsequently acquired the citizenship of the foreign country that such person may enjoy economic, social and cultural rights under the Federal law. (Part 2, Article 14)

Hence, the constitution has already embraced the need to build a more robust social, economic, and emotional connection with NRNs.

By executing the Non-Resident Nepali Act, 2008, as a significant legal provision to nonresident Nepalis, the government has enclosed Nepali Diaspora in the nation and statebuilding process. It has provisioned to offer NRN Cards to Non-resident Nepali (Article, 4(1)), the privilege to open bank accounts for the amount earned by him/her in convertible currency in any commercial bank or the financial institution (Article, 6), to invest in business or firm or to own company (Article 7), and to repatriate the investment and the amount equivalent to the profit earned in convertible foreign currency (Article, 9), to purchase land or other property to reside in Nepal (Article 10) and to receive ten years of visa at a time (Article 11). Hence, the Non-resident Act has accepted NRNs as an essential aspect of economic diplomacy and tried to enhance their attachment towards Nepal.

The government is taking initiatives to encourage and facilitate NRN's investment through economic diplomacy. It is continuously striving to attract investment in the export trade and tourism sector and focusing on foreign employment management, technology transfer, climate change and financing. The government is also planning to conduct a census like the NRN survey to take stock of NRN expertise and explore a suitable area of their engagements (MOFA, 2018). 


\section{Diaspora Diplomacy: Emerging Priority of Nepal's Foreign Policy}

Similarly, under the policies regarding labor and employment, the constitution has also spoken about the adoption of national policies for regulating and managing foreign employment to make this sector exploitation free, safe, and well-managed to guarantee labor right and encouraging the use of the capital, skill, technology and the experience gained in foreign employment in the productive sector of the country (Part 4, Article 51).

The government has proclaimed the Foreign Employment Act 2007 as a primary legal framework in Nepal to make foreign employment business safe, decent, and managed. Foreign Employment Rules, 2019 and Foreign Employment Tribunal, 2012, formed according to the same Act, has set the legal framework for the welfare of migrant workers and for handling disputes related to foreign employment.

The Ministry of Labour, Employment, and Social Security is the apex governmental body established in 1981 to formulate acts and regulations on labor and employment-related issues. It concludes the treaties, agreements, and MoUs with other governments to ensure migrants' protection and their rights. Department of Foreign Employment was established later in 2008 to handle the increased workload and complexity of foreign employmentrelated tasks. This department dedicatedly works for the welfare of labor migrants, like providing skills training to prospective migrants, issuing them labor permits, keeping their records, ensuring their protection in destination countries, and coordinating in giving relief and compensation (if needed) to the workers (Department of Foreign Employment, 2020).

Likewise, the Ministry of Foreign Affairs is exercising its functions as the apex governmental institution in formulating and implementing Nepal's foreign policy; strengthening Nepal's bilateral, regional and multilateral relations; promoting Nepal's development and economic diplomacy, protecting the rights and interests of Nepalis living abroad and handling passports and consular related matters. 39 Nepali missions (30 embassies, 3 permanent missions, and 6 consulates-general) have been established in various countries. A dedicated labor attaché' is also posted to the Embassies to hear and address labor issues in the missions (MOFA, 2020).

Upon realizing the increasing number of experts in various sectors such as engineering, medicine, economics, research, academics, etc., Nepal's government has created a platform called Brain Gain Center in May 2019 with a motive to form their database (MOFA, 2020). It is a user-oriented computer-based system where Nepali experts can register themselves. In the context of the alarming brain drain from a small and developing country like ours, the brain gain center aims to recognize the diaspora's expertise and to tap their knowledge and commitment to fulfill the national aspirations for sustainable peace, good governance, development, and prosperity. It is monitored and regulated by MOFA in Kathmandu.

Hence, all these legal and institutional provisions show Nepal's priority in diaspora diplomacy in the present day.

\section{Prominent issues of Nepali diaspora}

Despite the government's focus on diaspora diplomacy, there still exist numerous challenges and unsolved issues related to the Nepali diaspora. Some legal provisions are absolute in the present context while some require time to time revision. The Nepali diasporas are raising their voice for their space and participation in state mechanisms in more significant ways. 


\section{Diaspora Diplomacy: Emerging Priority of Nepal’s Foreign Policy}

They are demanding the upgrade in conventional working style in the administration to a more pragmatic and transparent manner. Thousands of Nepali experts working in various countries are willing to return to Nepal. But they are complaining that the government has been unable to assure them the opportunities to utilize their expertise in the related fields.

The current constitution has inked the provision to issue a non-resident Nepali citizenship certificate to the non-resident Nepalis. But the new Citizenship Act assuring this right is yet to promulgate. Confusion among policymakers is still going on about the format of the certificate and the distribution process, i.e., there is still the confusion either to distribute certificates through the diplomatic missions or through the local authorities. Currently, citizenship-related issues are being handled by the local authorities. This has created chaos among the diasporas.

Besides this, the debate of granting dual citizenship to NRNs has come to the forefront. Any citizen of Nepal who voluntarily acquires the citizenship of any foreign country shall automatically lose the citizenship of Nepal (Nepali citizenship Act, 2006). But NRNs are advocating that acquiring citizenship of the adopted country becomes almost a necessity for various practical considerations like to utilize the privileges of employment, easy and free education and other privileges to children, participation in multiple social and economic activities, utilization of social benefits, pensions, ease of travel, etc. So, they are demanding not to seize their rights to receive a Nepali citizenship certificate and to get connected with Nepal, the land of their origin. Nevertheless, the issue of dual citizenship has invited twofaceted opinions. One group of analysts argues that countries like the U.S, Canada, UK, Australia, New Zealand, Israel, France, and Russia have already granted dual citizenship certificate policies, which has been proved fruitful. Thus, they are demanding that Nepal should also adopt the same approach claiming social, economic, development benefits to Nepal. In contrast, another group of analysts argues against issuing dual citizenship, highlighting security concerns.

Bureaucratic hurdles and delays are also other issues raised by the diaspora. They often complain about their frustration while seeking services in Nepal, especially related to immigration, NRN Cards, and investments. As a consequence, the country is deprived of investment, potentially worth billions of dollars.

Nepal is also lagging in providing voting rights to migrants, which is also a big issue in today's democratic society. A 2007 assessment by the International Institute for Democracy and Electoral Assistance (IDEA) recognized 115 countries and territories with legal provisions for overseas voting. Even some countries in Asia such as Afghanistan, Bangladesh, India, Indonesia, Japan, Laos, Malaysia, Philippines, Singapore and Thailand, have the privilege of overseas voting to their Diaspora (Agunias \& Newland, 2012). But no severe concern of Nepali authority is felt to offer this fundamental right to Nepali residing in foreign lands.

The Nepal government has signed bilateral labor agreements with just eight major labor destinations: Qatar, the UAE, South Korea, Bahrain, Japan, Jordan, Malaysia nd Mauritius. But Nepali are working in more than 167 countries worldwide. This state of having no labor agreements with the remaining countries has created a serious concern on the security of Nepali immigrants. 


\section{Diaspora Diplomacy: Emerging Priority of Nepal’s Foreign Policy}

Despite the enormous contribution of Nepali migrants towards development in both home and destination countries, they are vulnerable to labor exploitation and abuse. Unskilled and low-skilled Nepali workforce and rural women are continuously being forced into labor and trafficking (International Labour Organization, 2020). Many of them are the victims of racial discrimination and hate based on their origin, which is the heart-wrenching reality Nepali diasporas are still experiencing.

In recent days, COVID-19 has created disruptions in numerous sectors, nearly in every country in the world. Hence, ensuring the safety of Nepali nationals in the host countries and non-bias treatment to them by the host government as well as the safe repartition of those who have lost their foreign jobs back to Nepal are yet another immediate responsibilities that the Nepal government needs to act on. Hence, all these issues are the prominent ones that the government needs to deal with without any delay.

\section{Conclusion}

The government has promised to turn Nepal's long-awaited prosperity dream into a reality by exercising all possible means, but the results are not satisfactory. The most potential human resource, Nepali diasporas are continuously blaming the government for not creating a resilient relationship with them and not mobilizing their capacities. Identifying the Diasporas, keeping their records, building trust, and confidence with them are now the immediate needs policymakers should address. Nepal is now a federal country, so every possible mechanism at all central, federal, and local levels should be developed to connect with them. The use of modern technologies to guarantee trouble-free government service should be ensured. This will help the government to gain confidence, primarily in bringing their investment and skills to Nepal. To maximize the chances of using their expertise in diverse sectors and to ensure immediate and sustainable results, the efficiency of the Brain Gain Center should also be further enhanced. Diaspora residing in various countries have diverse exposure. So, priorities should be set, and work accordingly to utilize their skills. The laws should be enacted immediately, ensuring the right of non-resident Nepali to receive a non-resident Nepali citizenship certificate as well as the right of Nepali people residing in foreign lands to take part in national elections in Nepal.

In the context of the increasing expansion of migrants to hundreds of countries, the state agencies should speed up the negotiation process with the government of more countries and conclude labor agreements so that the labor rights of Nepali migrants are protected. The Ministry of Foreign Affairs should make a robust mechanism through the diplomatic missions for the quick rescue of the victims. The diplomatic staff should also be trained and equipped with all necessary resources so that their efficiency would further increase, and it would be easier to disseminate information and conduct programs for the safety and security of Nepali nationals.

Every Nepali Diaspora deserves to feel connected with the people, the government and the system back home. Hence, the best practices adopted by many other countries for utilizing diaspora in national development should be embraced so that mutual benefits between Nepal and Nepali diaspora are ensured based on the realities of today's globalized world. 


\section{Diaspora Diplomacy: Emerging Priority of Nepal's Foreign Policy}

\section{References}

Aquinas D.R., \& K. Newland. (2012, November). Engaging the Asian diaspora. Issues in Brief . Issue No. 7. IOM Region office for Asia and the Pacific and MPI. https://www.migrationpolicy.org/research/engaging-asian-diaspora

Amatya, P., Ghimire, S., Callahan, K. E., Baral, B. K., \& Poudel, K. C. (2018). Practice and lived experience of menstrual exiles (Chhaupadi) among adolescent girls in far-western Nepal. PloSone, 13 (12), e0208260. https://doi.org/10.1371/journal.pone.0208260

Caplan, L. (1995). Warrior gentlemen: "Gurkhas" in the estern imagination. Berghahn Books.

Emre Ok, Yunus (2018, November, 1) Diaspora diplomacy as a foreign policy strategy. Young Initiative for Foreign Affairs and International Relations e.V. https://ifair.eu/2018/11/01/diaspora-diplomacy-as-a-foreign-policy-strategy/

Government of Nepal Ministry of Law, Justie and Parliamentary Affairs (2007) Employment and Social Security. Foreign Employment Act (2007). Nepal Law Commission.

Gellner, D. N. (2013). Warriors, workers, traders, and peasants: The Nepali/gorkhali diaspora since the nineteenth century. In D. Washbrook and J. Chatterjee (eds). Routledge Handbook of South Asian Diaspora. Routledge. 137-138.

Gonzalez, J. J. (2011). Diaspora diplomacy: Philippine migration and its soft power influences. Mill City press.

Gellner, D., Hausner, S., Gurung, F., \& March, K. S. (2018). Global Nepalis: Religion, culture, and community in a new and old diaspora. Oxford University Press.

Goldstein, J.S. \& Jon C. P. (2009) International relations (Eight Edition). Pearson Dorling Kindersley India Pvt Ltd.

Ho, E. L. E., \& McConnell, F. (2019). Conceptualizing ‘diaspora diplomacy’: Territory and populations betwixt the domestic and foreign. Progress in Human Geography. 43 (2), 235255. https://doi.org/10.1177/0309132517740217.

Ieva Birka \& Didzis Kḷaviņš (2020) Diaspora diplomacy: Nordic and Baltic perspective. Diaspora Studies.13 (2), 115-132. https://doi.org/10.1080/09739572.2019.1693861

International Organization for Migration. (2019). Migration in Nepal: A country profile. IOM, Baluwatar. https://publications.iom.int/books/migration-nepal-country-profile-2019.

Levitt, P. (2001). Transnational migration: taking stock and future directions. Global Networks, (Vol. 1, No 3, pp.195-216). https://doi.org/10.1111/1471-0374.00013

Nepalisansar.com. (2019, August 24). Foreign education. Nepali Sansar. https://www.nepalisansar.com/education/nepal-foreign-education-department-as-many-as323972-students-studying-abroad/ 


\section{Diaspora Diplomacy: Emerging Priority of Nepal's Foreign Policy}

Non-resident Nepali Organization (2015). NRN investment in Nepal: A survey of nine selected districts. Society of Economic Journalists- Nepal. https://nrna.org/Portals/0/pdf/ nrn_investment_research_report.pdf

Pew Research Center. (2017, September 8). Nepali in U.S. Pew Research Organization. https://www.pewsocialtrends.org/chart/Nepali-population-in-the-u-s/

Rana, K. S. (2011). 21st-Century diplomacy: A practitioner's guide. Bloomsbury Publishing.

Regmi, D. R. (1984). Ancient and medieval Nepal. United States: (n.p.).

Sharp, Paul. (2019). Diplomacy in the 21st century: A brief introduction. Taylor \& Francis.

Stengel, F. A., \& Baumann, R. (2017). Non-state actors and foreign policy. In Oxford Research Encyclopedia of Politics. https://doi.org/10.1093/ acrefore/ 9780190228637. 013.456

Government of Nepal, Ministry of Law, Justice and Parliamentary Affairs. (2015). The constitution of Nepal. (2072). Law Books Management Board.

United Nations. Department of Social and Economic Affairs, Population Division. (2019). International Migration Report. Report (ST/ESA/SER.A/438). https://www.un.org/en/ development/desa/population/migration/publications/migrationreport/docs/InternationalMigr ation2019_Report.pdf

Vaidya, R. (2019). Foreign employment: Legal framework and its legal cases in Nepal. International Journal of Law Policy and Social Review. 1(4), 11-16. http://www.lawjournals.net/article/view/27/1-4-13

Walker, C.T. \& Rousseau, D. L. (2018). Liberalism: A theoretical and empirical assessment. In M.D. Cavelty \& T. Balzacq. Routledge handbook of security studies (sec. ed., pp. 22-31). Routledge Taylor \& Francis Group. 